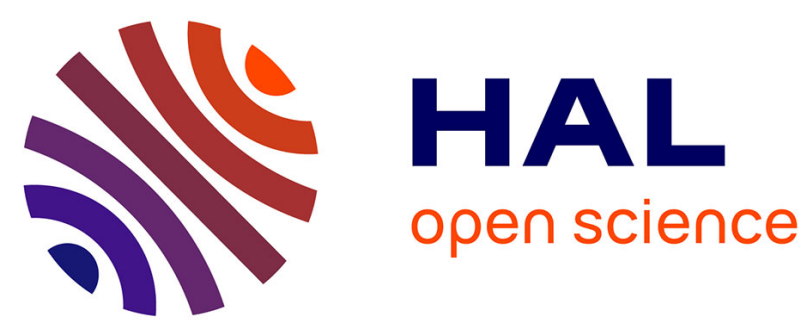

\title{
Evaluation of the performance of HPLC-CHEMTAX analysis for determining phytoplankton biomass and composition in a turbid estuary (Schelde, Belgium)
}

\author{
Marie Lionard, Koenraad Muylaert, Michèle Tackx, Wim Vyverman
}

\section{- To cite this version:}

Marie Lionard, Koenraad Muylaert, Michèle Tackx, Wim Vyverman. Evaluation of the performance of HPLC-CHEMTAX analysis for determining phytoplankton biomass and composition in a turbid estuary (Schelde, Belgium). Estuarine, Coastal and Shelf Science, 2008, 76 (4), pp.809-817. 10.1016/j.ecss.2007.08.003 . hal-01516151

\author{
HAL Id: hal-01516151 \\ https://hal.science/hal-01516151
}

Submitted on 28 Apr 2017

HAL is a multi-disciplinary open access archive for the deposit and dissemination of scientific research documents, whether they are published or not. The documents may come from teaching and research institutions in France or abroad, or from public or private research centers.
L'archive ouverte pluridisciplinaire HAL, est destinée au dépôt et à la diffusion de documents scientifiques de niveau recherche, publiés ou non, émanant des établissements d'enseignement et de recherche français ou étrangers, des laboratoires publics ou privés. 


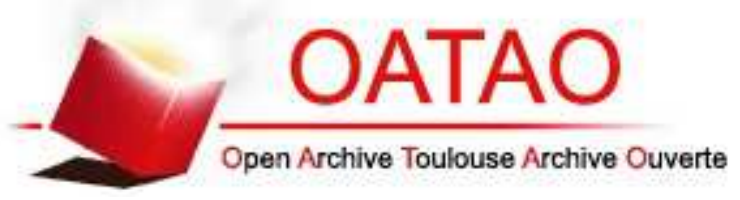

\section{Open Archive TOULOUSE Archive Ouverte (OATAO)}

OATAO is an open access repository that collects the work of Toulouse researchers and makes it freely available over the web where possible.

This is an author-deposited version published in : http://oatao.univ-toulouse.fr/ Eprints ID : 4436

To link to this article : DOI:10.1016/j.ecss.2007.08.003

URL : http://dx.doi.org/10.1016/j.ecss.2007.08.003

To cite this version : Lionard, Marie and Muylaert, Koenraad and Tackx, Michèle and Vyverman, Wim Evaluation of the performance of HPLC-CHEMTAX analysis for determining phytoplankton biomass and composition in a turbid estuary (Schelde, Belgium). (2008) Estuarine, Coastal and Shelf Science, vol. 76 ( $\left.\mathrm{n}^{\circ} 4\right)$. pp. 809817. ISSN 0272-7714

Any correspondence concerning this service should be sent to the repository administrator: staff-oatao@ listes-diff.inp-toulouse.fr 


\title{
Evaluation of the performance of HPLC-CHEMTAX analysis for determining phytoplankton biomass and composition in a turbid estuary (Schelde, Belgium)
}

\author{
Marie Lionard ${ }^{\mathrm{a}, *}$, Koenraad Muylaert ${ }^{\mathrm{b}}$, Michèle Tackx ${ }^{\mathrm{c}}$, Wim Vyverman ${ }^{\mathrm{a}}$ \\ ${ }^{a}$ Laboratory of Protistology and Aquatic Ecology, Biology Department, University of Gent, Krijgslaan 281 S8, B-9000 Gent, Belgium \\ ${ }^{\mathrm{b}}$ K.U. Leuven Campus Kortrijk, E. Sabbelaan 53, B-8500 Kortrijk, Belgium \\ ${ }^{\mathrm{c}}$ Laboratoire d'Ecologie Fonctionnelle (EcoLab), UMR 5245 CNRS/UPS, 29, rue Jeanne Marvig, 31055 Toulouse Cedex 4, France
}

\begin{abstract}
In the upper Schelde estuary in 2002, phytoplankton biomass and community composition were studied using microscopic and pigment analyses. Chlorophyll $a$ concentration was a good predictor of phytoplankton biomass estimated from cell counts and biovolume measurements. The phytoplankton carbon to chlorophyll $a$ ratio, however, was often unrealistically low $(<10)$. CHEMTAX was used to estimate the contribution of the major algal groups to total chlorophyll $a$. The dominant algal groups were diatoms and chlorophytes. While diatom equivalents in chlorophyll $a$ predicted diatom biomass relatively well, chlorophyte equivalents in chlorophyll $a$ were only weakly related to chlorophyte biomass. The pigment-based approach to study phytoplankton overestimated phytoplankton biomass in general and chlorophyte biomass in particular in late autumn and winter, when phytoplankton biomass was low. A possible explanation for this overestimation may be the presence of large amounts of vascular plant detritus in the upper Schelde estuary. Residual chlorophyll $a$, chlorophyll $b$ and lutein in this detritus may result in an overestimation of total phytoplankton and chlorophyte biomass when the contribution of phytoplankton to total particulate organic matter is low.
\end{abstract}

Keywords: CHEMTAX; chlorophytes; diatoms; detritus; Schelde estuary

\section{Introduction}

Traditionally, phytoplankton abundance and community composition have been studied using microscopic cell counts. Such microscopic analyses, however, are time-consuming and require a thorough taxonomic expertise. Although the method provides accurate information about the community composition of the phytoplankton, the precision is low unless a very large number of cells are counted. Using biovolume measurements and appropriate conversion factors (e.g. Menden-Deuer

\footnotetext{
* Corresponding author. Present address: Institut des Sciences de la mer de Rimouski (ISMER), Université du Québec à Rimouski, 310 allée des Ursulines, C.P. 3300, Rimouski, Québec, Canada G5L 3A1.

E-mail addresses: marie.lionard@uqar.qc.ca (M. Lionard), koenraad. muylaert@kuleuven-kortrijk.be (K. Muylaert), tackx@cict.fr (M. Tackx).
}

and Lessard, 2000), abundance data can be converted to biomass, but such a conversion further reduces the precision of the analysis due to the high variability in biovolume of most species.

Spectrophotometric or fluorometric chlorophyll $a$ analyses have long been used as a proxy for total phytoplankton biomass. Since the 1980s, HPLC analysis of phytoplankton accessory pigments has increasingly been used to study not only biomass but also community composition of phytoplankton (Gieskes and Kraay, 1983). The software CHEMTAX, which was developed about a decade ago, is now a commonly used tool to reconstruct phytoplankton community composition from accessory pigment concentrations derived from HPLC analyses (Mackey et al., 1996). Pigment analyses are usually faster, require less taxonomic knowledge of the analyst and generally yield more precise measurements when compared 
to microscopic analyses. However, as an estimate of phytoplankton biomass and community composition, pigment analyses are not necessarily accurate. This is due to the fact that pigment to biomass ratios, and accessory pigment to chlorophyll $a$ ratios, vary with environmental conditions (e.g. Geider, 1987; Schlüter et al., 2000). Moreover, pigment to chlorophyll $a$ ratios may differ between species of the same algal group (Mackey et al., 1998).

In macrotidal estuaries, high suspended matter concentrations often hamper microscopic enumeration of phytoplankton. Therefore, in these ecosystems, pigment analyses would be a useful alternative for microscopic counts to study the biomass and composition of phytoplankton. Due to an unfavourable light climate, a short retention time and fluctuating salinities, phytoplankton communities in macrotidal estuaries are often relatively simple and dominated by only a few algal groups (e.g. Muylaert et al., 2000). If no algae with unusual pigment signatures are present (e.g. peridinin-lacking dinoflagellates, Rodriguez et al., 2002), phytoplankton community composition can be expected to be easily reconstructed using HPLC-CHEMTAX analysis. HPLC-CHEMTAX analyses have previously been applied in estuaries to reconstruct phytoplankton community composition and results have been verified with microscopic analyses (e.g. Schlüter et al., 2000; Carreto et al., 2003). These studies usually focused on the relatively clear marine sections of estuaries and did not take into account the most turbid upper reaches. In these turbid upper reaches, several factors may confound the use of pigments as a proxy for phytoplankton biomass and community composition. Due to the low light levels, phytoplankton carbon to total chlorophyll $a$ ratios may be lower than in the marine section of estuaries (Geider, 1987). Therefore, phytoplankton biomass estimates based on chlorophyll $a$ measurements and chlorophyll $a$ to carbon conversion factors used in other aquatic ecosystems may result in an overestimation of phytoplankton biomass. Moreover, macrotidal estuaries often receive and accumulate large amounts of detritus, originating from aquatic macrophytes or terrestrial vegetation. Pigments present in this detritus might influence CHEMTAX analyses as the pigment signature of terrestrial plants is identical to that of chlorophytes, an often dominant phytoplankton group in the upper reaches of estuaries (Muylaert et al., 2005).

In this study, we compare estimates of phytoplankton biomass and community composition using HPLC-CHEMTAX with results from microscopic analyses in the turbid, upper reaches of the Schelde estuary.

\section{Materials and methods}

\subsection{Study site}

The Schelde is a macrotidal estuary shared by Belgium and The Netherlands (Fig. 1). The water column is well-mixed throughout the estuary. The high anthropogenic pressure on the estuary results in high concentrations of inorganic nutrients (Baeyens et al., 1998). The estuary has an extensive maximum turbidity zone in its upper reaches (between Dendermonde and Antwerp) where suspended particulate matter (SPM) concentrations usually exceed $50 \mathrm{mg}^{-1}$ (Van Damme et al., 2005). In this part of the estuary, phytoplankton primary production is strongly light-limited (Muylaert et al., 2005). Nevertheless, phytoplankton may attain a high biomass, as is indicated by chlorophyll $a$ concentrations of up to $700 \mu \mathrm{g} 1^{-1}$ (Marie Lionard, unpublished results). Phytoplankton blooms usually occur in spring and in summer, with the spring bloom being imported from the Schelde River and the summer bloom being produced within the freshwater tidal reaches of the estuary (Muylaert et al., 2001). The phytoplankton community in the upper Schelde estuary is relatively simple and tends to be dominated by diatoms throughout the year, with chlorophytes

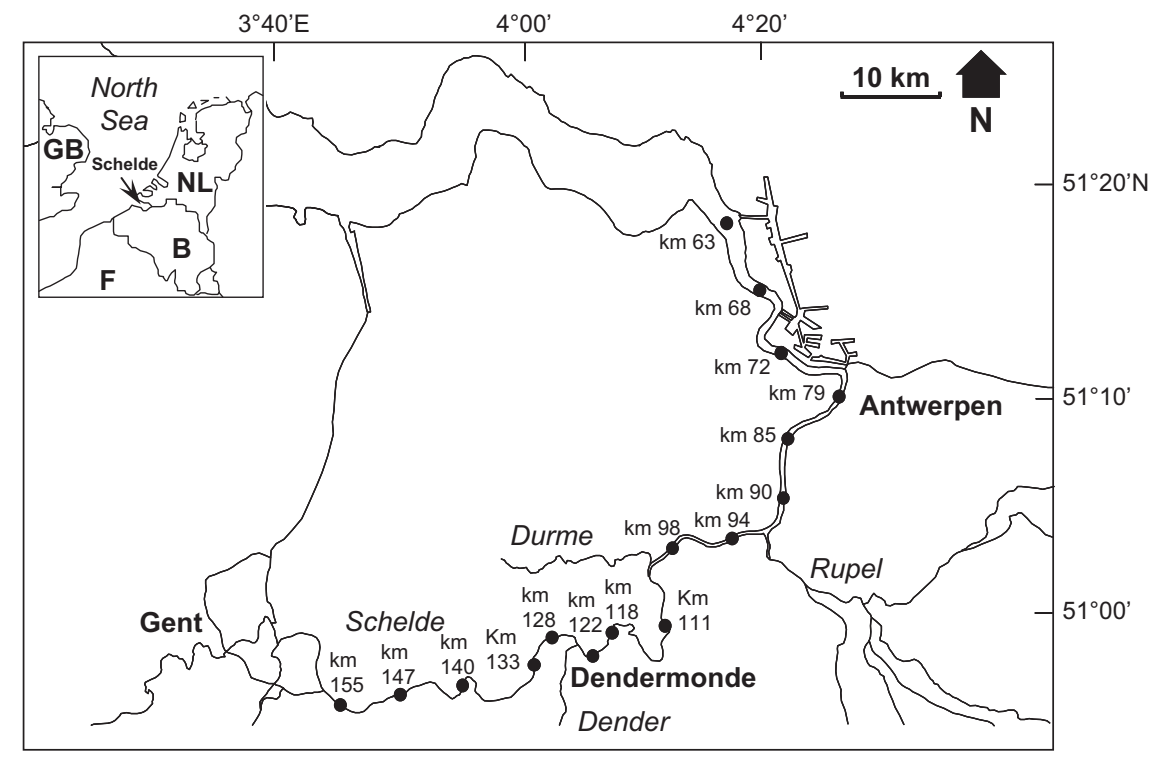

Fig. 1. Map of the Schelde estuary showing the location of the sampling stations (black dots) and their distance from the mouth of the estuary. Abbreviations used for countries are: B for Belgium, F for France, GB for Great Britain and NL for Netherlands. 
contributing significantly to phytoplankton biomass in summer (Muylaert et al., 2000; Lionard et al., 2005). Prasinophytes and picoplankton were neither observed in the Schelde estuary during this study nor in the previous ones (Muylaert et al., 2000; Lionard et al., 2005).

\subsection{Sampling and analyses}

The upper reaches of the Schelde estuary were sampled monthly in 2002 at 16 stations situated along the longitudinal estuarine gradient (Fig. 1). The 10 most upstream stations of this transect were situated in the freshwater tidal reaches (salinity $<0.5$ ) while the downstream stations covered part of the salinity gradient (up to 11.5 at the most downstream site in summer). Sub-surface water samples were collected in the main channel by means of bucket hauls from a ship.

A sample for microscopic analysis was fixed with Lugol's solution in the field and post-fixed for long-term preservation with formalin (final concentration $4 \%$ ) in the lab within one month of sampling. No samples for microscopic analysis were available for January and February. In each sample, 100 phytoplankton 'units' (cells, coenobia or colonies) were enumerated and identified using an inverted microscope. To facilitate enumeration of phytoplankton in the presence of high amounts of sediment and detritus, Bengal Rose was added to the samples and small sample volumes $(5-10 \mathrm{ml})$ were concentrated in the sedimentation chambers. For each month, the biovolume of at least 15 'units' of each species was measured in different samples from the estuarine gradient sampled. When $<15$ 'units' were encountered during the analyses of the 16 samples from each month, data from consecutive months were combined. Phytoplankton biovolume was converted to carbon biomass using published conversion factors (Menden-Deuer and Lessard, 2000).

For analysis of phytoplankton pigments, 250-500 ml water was filtered over a $25-\mathrm{mm}$ diameter Whatman GF/F glass fibre filter. The filter was wrapped in an aluminium foil, stored on ice on board the ship and during transport and stored at $-80{ }^{\circ} \mathrm{C}$ in the lab. Pigments were extracted from the filter in $90 \%$ acetone by means of sonication (tip sonicator, $40 \mathrm{~W}$ for $30 \mathrm{~s}$, Wright et al., 1997). The pigment extracts were filtered over a $0.2 \mu \mathrm{m}$ Alltech nylon syringe filter and injected into a Gilson HPLC system equipped with an Alltima reversephase $\mathrm{C} 18$ column $(25 \mathrm{~cm} \times 4.6 \mathrm{~mm}, 5 \mu \mathrm{m}$ particle sizes $)$. Pigments analysed according to the method of Wright and Jeffrey (1997), which is an adaptation of the method of Wright et al. (1991). This method uses a gradient of three solvents: methanol 80\%-ammonium acetate 20\%, acetonitrile $90 \%$ and ethyl acetate. Three detectors were connected to the HPLC system: an Applied Biosystems 785A detector to measure absorbance at $785 \mathrm{~nm}$, a Gilson model 121 fluorometer to measure fluorescence of chlorophylls and their derivates and a Gilson 170 diode array detector (DAD) to measure absorbance spectra for individual pigment peaks. Pigments were identified by comparison of retention times and absorption spectra with pure pigment standards (supplied by DHI, Denmark). Pigments detected and quantified in the HPLC analyses were the chlorophylls $a, b$ and $c$ and the carotenoids peridinin, fucoxanthin, neoxanthin, violaxanthin, diadinoxanthin, alloxanthin, diatoxanthin, lutein, zeaxanthin, echinenone and $\beta$-carotene. Derivatives of chlorophyll $a$ detected were chlorophyllide $a$, pheophorbide $a$, pheophytin $a$ and chlorophyll $a$ allomer and epimer.

\subsection{Statistical analyses}

The CHEMTAX software (Mackey et al., 1996) was used to calculate the contribution of major algal groups to total chlorophyll $a$ using concentrations of accessory pigments. The CHEMTAX software uses three matrices: (1) a matrix containing concentrations of all accessory pigments in the samples; (2) an initial matrix containing accessory pigment to chlorophyll $a$ ratios for all algal groups present in the sample; and (3) a limit matrix defining limits on the accessory pigment to chlorophyll $a$ ratios. The CHEMTAX program optimizes the contribution of different algal groups to total chlorophyll $a$ based on measured pigment concentrations (matrix 1), using the pigment ratio matrix (matrix 2) as a starting point and allowing pigment ratio's to vary according to constraints defined in the limit matrix (matrix 3). The initial pigment ratio matrix (matrix 2) included all algal groups detected during the microscopic analyses: diatoms, chlorophytes, cryptophytes, cyanobacteria, dinoflagellates and euglenophytes. The pigments detected did not indicate the presence of other algal groups during this study. The initial pigment ratio matrix (Table 1) was based on published accessory pigment to chlorophyll $a$ ratios in estuaries (Schlüter et al., 2000; Lewitus et al., 2005) as well as measured from cultures of dominant diatoms (Cyclotella sp. and Stephanodiscus sp.) isolated from the freshwater reaches of the Schelde estuary during this study. Due to the interconversion between diadinoxanthin and diatoxanthin with changes in light climate, the sum of these

Table 1

CHEMTAX pigment ratio table, derived from analysis of all samples combined. Within each cell, the initial value is followed by the final value

\begin{tabular}{|c|c|c|c|c|c|c|c|c|}
\hline & Peridinin & Fucoxanthin & Diadinoxanthin, diatoxanthin & Alloxanthin & Lutein & Zeaxanthin & Echinenone & Chlorophyll $b$ \\
\hline Chlorophytes & 0 & 0 & & 0 & $0.251-0.248$ & $0.030-0.053$ & 0 & $0.293-0.240$ \\
\hline Cryptophytes & 0 & 0 & & $0.247-0.233$ & 0 & 0 & 0 & 0 \\
\hline Cyanobacteria & 0 & 0 & & 0 & 0 & $0.040-0.050$ & $0.126-0.096$ & 0 \\
\hline Diatoms & 0 & $0.697-0.605$ & $0.126-0.089$ & 0 & 0 & 0 & 0 & 0 \\
\hline Dinophytes & $0.760-0.762$ & 0 & $0.400-0.339$ & 0 & 0 & 0 & 0 & 0 \\
\hline Euglenophytes & 0 & 0 & $0.330-0.343$ & 0 & 0 & 0 & 0 & $0.475-0.393$ \\
\hline
\end{tabular}


two pigments was used in the analyses. As the method of Wright et al. (1991) does not allow distinguishing between the different chlorophyll $c$ s, these chlorophylls were excluded from the CHEMTAX analyses. Violaxanthin was excluded from the CHEMTAX matrix due to its co-elution of with pheophorbide $a$, while neoxanthin was excluded due to its low concentration and the difficulty to identify it with certainty. Pigment ratios in the final pigment ratio matrix changed only slightly with respect to the initial matrix provided, indicating that phytoplankton pigment ratios used were adapted to phytoplankton communities observed in the Schelde estuary (Table 1).

Linear regression was used to test for the relation between microscopic and pigment-based measurements. Pearson's correlation coefficients were calculated to relate discrepancies between the microscopic and pigment-based approach to environmental variables. Data were log-transformed to approach normal distribution.

\section{Results}

Chlorophyll $a$ concentration (Fig. 2A) varied between 1 and $206 \mu \mathrm{gl}^{-1}$ and had a mean of $35 \mu \mathrm{g} \mathrm{l^{-1 }}$ and a median of $21 \mu \mathrm{gl}^{-1}$. Phytoplankton biomass as estimated from microscopic counts (Fig. 2B) varied between 7 and $2163 \mu \mathrm{g} \mathrm{Cl}^{-1}$ and had a mean of $435 \mu \mathrm{g} \mathrm{Cl}^{-1}$ and a median of $225 \mu \mathrm{g} \mathrm{Cl}^{-1}$. Chlorophyll $a$ concentration and phytoplankton biomass displayed two maxima in the upper Schelde estuary in 2002. The first maximum occurred in spring and was situated in the upper estuary, near the transition from river to estuary. The other maximum occurred in summer and was situated more downstream but still within the freshwater part of the estuary. Throughout the year, chlorophyll $a$ and phytoplankton biomass declined in the brackish reaches.

Chlorophyll a concentration was closely correlated with phytoplankton biomass (Pearson's correlation coefficient: $r=0.81, p<0.001, n=159$ ) (Fig. 3). The phytoplankton carbon to total chlorophyll ratio (Fig. 4) varied between 1 and 70 and had a mean of 15 and a median of 10 . In $40 \%$ of the samples, the phytoplankton carbon to total chlorophyll $a$ ratio was between 10 and 30 and in only $10 \%$ of the samples it exceeded 30. The phytoplankton carbon to total chlorophyll $a$ ratio was on average higher in spring and summer and was lower in winter and autumn. As a result, the ratio was positively related to temperature (Pearson's correlation coefficient: $r=0.49, p<$ $0.01, n=148)$.

Both microscopic analyses and HPLC-CHEMTAX analyses identified diatoms and chlorophytes as the algal groups with the highest contribution to biomass or total chlorophyll $a$ (Table 2). The annual average contribution of other algal groups to total phytoplankton biomass or chlorophyll $a$ was $<10 \%$. On an annual average basis, the HPLC-CHEMTAX approach underestimated the importance of diatoms and overestimated the importance of other algal groups in the phytoplankton community. For diatoms, the spatio-temporal distribution pattern revealed by the microscopic analyses and the HPLC-CHEMTAX approach corresponded well (Fig. 5). Both approaches revealed a diatom bloom in spring (April-May) and in summer to early autumn (June-October), with the spring bloom lasting shorter and having a maximum that was situated slightly more upstream in the estuary than the summer to autumn bloom. For chlorophytes, the spatio-temporal distribution revealed by the microscopic approach differed substantially from that revealed by the HPLC-CHEMTAX approach. The microscopic approach (Fig. 6A) pointed to elevated
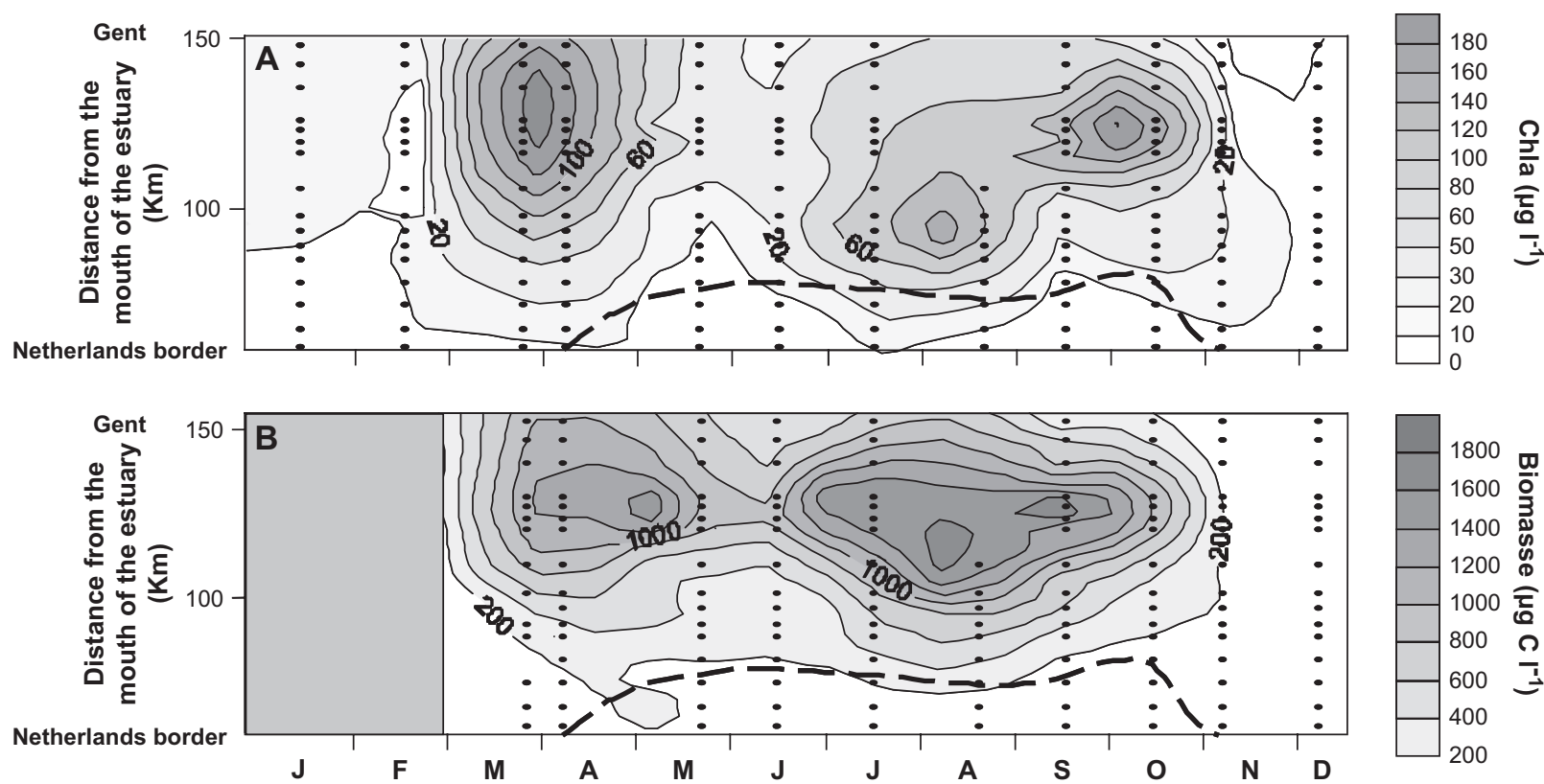

Fig. 2. Spatio-temporal variation of chlorophyll $a$ concentration $\left(\mu \mathrm{g} 1^{-1}, \mathrm{~A}\right)$ and phytoplankton biomass $\left(\mu \mathrm{g} \mathrm{C} 1^{-1}\right.$, B) in the upper Schelde estuary in 2002 . The 5 psu isohaline is represented by the dotted line. Black dots represent sample points in space and time. 


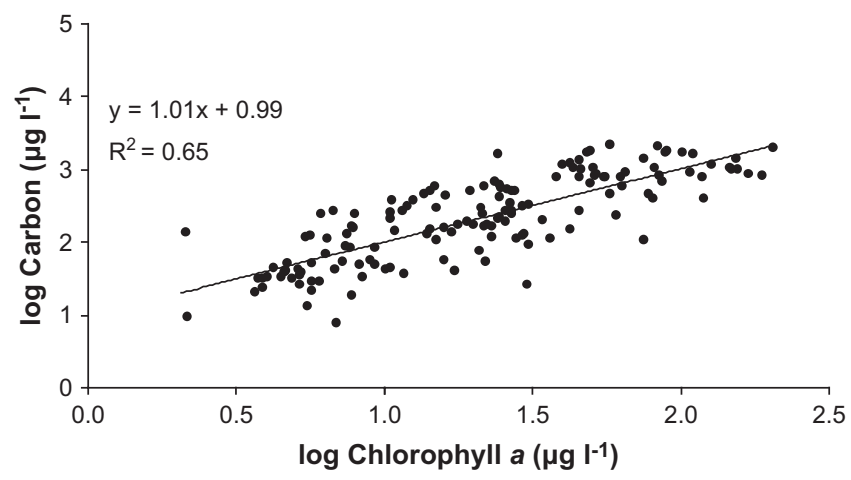

Fig. 3. Regression of phytoplankton biomass $\left(\log \mu \mathrm{g} \mathrm{C}^{-1}\right)$ against chlorophyll $a$ concentration $\left(\log \mu \mathrm{g} \mathrm{l}^{-1}\right)$. Pearson's correlation coefficient: $r=0.81, p<$ $0.001, n=159$.

chlorophyte biomass from June to September in the upper estuary and very low chlorophyte biomass outside that period and a decrease towards the brackish reaches. The HPLCCHEMTAX approach (Fig. 6B) also indicated a high chlorophyte biomass in summer in the upper reaches, but pointed to a relatively high biomass in April. While the microscopic method indicated that the chlorophytes were absent in winter, the HPLC-CHEMTAX method did detect chlorophytes during winter.

Diatom equivalents in chlorophyll $a$ estimated using CHEMTAX predicted the biomass of diatoms estimated using microscopy relatively well (Pearson's correlation coefficient: $r=0.85, p<0.001, n=148$; Fig. 7A). For chlorophytes, however, the CHEMTAX estimate of the contribution to chlorophyll $a$ was a very poor predictor of chlorophyte biomass determined microscopically (Pearson's correlation coefficient: $r=0.40, p<0.001, n=148$; Fig. 7B). The residuals of the regression of chlorophyte biomass versus the contribution of chlorophytes to chlorophyll $a$ were significantly negatively related to temperature (Pearson's correlation coefficient: $r=$ $0.59, p<0.001, n=149$; data not shown), indicating that the CHEMTAX method overestimated the chlorophyte contribution to chlorophyll $a$ mainly in winter. The residuals from the regression of chlorophyte biomass versus chlorophytes equivalents in chlorophyll $a$ were also closely negatively correlated with the phytoplankton carbon to total chlorophyll $a$ ratio (Pearson's correlation coefficient: $r=-0.51, p<0.001$, $n=146$; Fig. 8).

\section{Discussion}

The two independent measures of phytoplankton biomass and community composition performed in 2002, cell counts and pigment data, revealed the same spatio-temporal pattern. With respect to the total phytoplankton biomass, the microscopic and the pigment-based approaches both revealed two bloom events: a spring bloom that had its maximum near the head of the estuary and a summer bloom that was situated more downstream in the estuary but still in the freshwater tidal zone. The microscopic and pigment-based approaches both pointed towards the dominance of the phytoplankton community by diatoms and chlorophytes, with diatoms generally being most abundant. Both methods also pointed to a dominance of the spring and summer blooms by diatoms, with chlorophytes being important particularly in summer in the upper estuary. These observations are in line with previous studies on phytoplankton biomass and community composition in the upper Schelde estuary based on data collected in 1996 (Muylaert and Sabbe, 1999; Muylaert et al., 2005). In 1996, spring and summer blooms were also observed, with the spring bloom having a maximum that was situated more upstream than the summer bloom. In 1996, diatoms also dominated both blooms while chlorophytes were mainly important during summer in the upper estuary.

Although the microscopic and the pigment-based approaches yielded a similar general picture of phytoplankton biomass and community composition in the upper Schelde estuary, some marked discrepancies were observed. First, the phytoplankton carbon to total chlorophyll $a$ ratio estimated from microscopic cell counts and biovolume measurements was on average very low. A low carbon to chlorophyll $a$ ratio was to be expected in the turbid and largely freshwater upper reaches of the Schelde estuary, as the carbon to chlorophyll $a$ ratio in phytoplankton is known to decline with decreasing light levels (e.g. Geider, 1987; Thompson, 1999) and is known to be lower in freshwater than in marine environments (Maskymowska et al., 2000). A decline nevertheless, in half of the samples, the phytoplankton carbon to total chlorophyll $a$

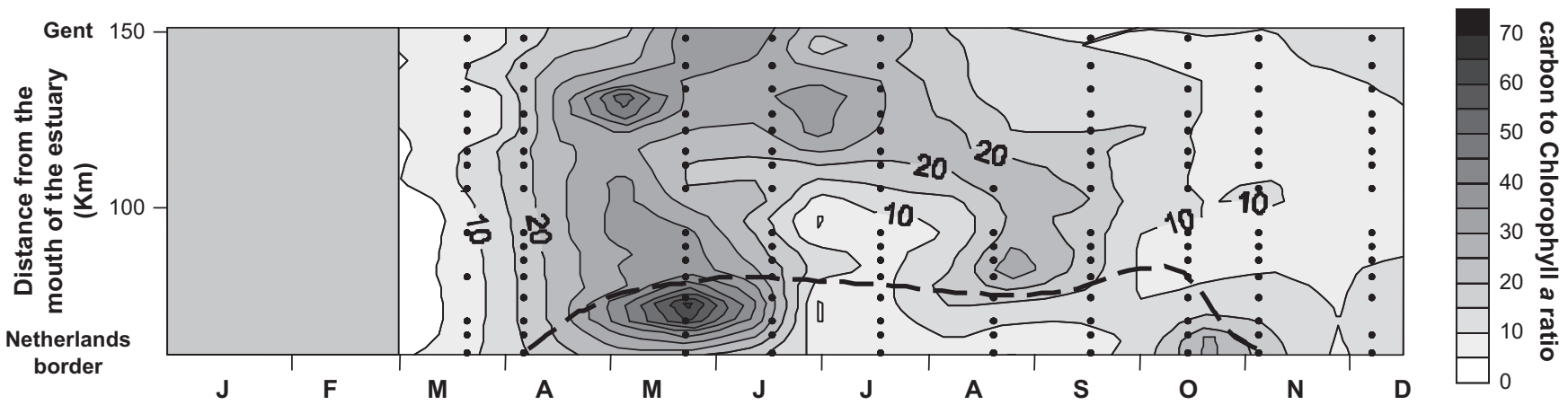

Fig. 4. Spatio-temporal variation of the phytoplankton carbon to chlorophyll $a$ ratio in the upper Schelde estuary in 2002 . The 5 psu isohaline is represented by the dotted line. Black dots represent sample points in space and time. 
Table 2

Annual average percentage contribution of algal groups to chlorophyll $a$ and to biomass

\begin{tabular}{lll}
\hline & CHEMTAX & Microscope \\
\cline { 2 - 3 } & Annual average & Annual average \\
\hline Diatoms & $59.0 \%$ & $77.1 \%$ \\
Chlorophytes & $20.0 \%$ & $14.3 \%$ \\
Dinophytes & $1.1 \%$ & $0.1 \%$ \\
Cyanobacteria & $6.6 \%$ & $2.9 \%$ \\
Euglenophytes & $5.6 \%$ & $2.5 \%$ \\
Cryptophytes & $7.8 \%$ & $3.1 \%$ \\
\hline
\end{tabular}

ratio was estimated to be $<10$, which is unrealistically low. In laboratory cultures as well as in field studies, the carbon to chlorophyll $a$ ratio rarely drops below 20 and values below 10 have never been reported (Geider, 1987; Thompson, 1999).

A second problem in the comparison between the microscopic and the pigment-based approach was the fact that the chlorophyte biomass estimated by HPLC-CHEMTAX was very weakly correlated with the microscopic estimate of chlorophyte biomass. The weak correlation between these two methods might be due to the fact that the chlorophytes were relatively uncommon and that relatively few cells were counted per sample. As a result of this, the accuracy of the microscopic method would be expected to be low, increasing the random error in the estimate of chlorophyte biomass. However, the error on the microscopic estimate of chlorophyte biomass was not randomly distributed. The residuals of the regression of microscopically estimated biomass versus biomass estimated by HPLC-CHEMTAX displayed a clear pattern, with a systematical overestimation of chlorophyte biomass in winter.

The degree of overestimation of chlorophyte biomass by the HPLC-CHEMTAX method was closely correlated with the phytoplankton carbon to total chlorophyll $a$ ratio. This suggests that the two observed discrepancies between the pigmentbased and microscopic approach had a common cause. It therefore appears that either HPLC-CHEMTAX overestimated or microscopy underestimated total phytoplankton biomass in general and chlorophyte biomass in particular in winter and towards the brackish reaches. Microscopic methods have previously been reported to underestimate biomass of small pico- or ultra-planktonic phytoplankton because small algae are easily overlooked during microscopy (e.g. Ansotegui et al., 2003). Although pico- to ultra-planktonic chlorophytes or prasinophytes were not included in the microscopic counts in this study, it is unlikely that this explains the discrepancy between the microscopic and the HPLC-CHEMTAX method. Pico- and ultra-planktonic eukaryotes have been detected using epifluorescence microscopy in a previous study of phytoplankton community composition in the upper Schelde estuary (Muylaert and Sabbe, 1999). However, they occurred mainly in summer and even then they did not contribute significantly to total phytoplankton biomass.

HPLC-CHEMTAX may overestimate chlorophyte biomass if chlorophyte pigments occur in other particles than phytoplankton. Vascular plants have the same pigment signature as chlorophytes, with chlorophyll $b$ and lutein being the main accessory pigments. Estuaries in general receive important inputs of vascular plant detritus (e.g. Riera and Richard, 1996). Along the upper Schelde estuary, productive macrophyte stands (predominantly reed, Phragmites australis) occur on intertidal marshes. The reed stands cover half of the total intertidal marsh area of $4.5 \mathrm{~km}^{2}$ and produce $1.8 \mathrm{~kg} \mathrm{C} \mathrm{m}^{-2}$ year $^{-2}$ (Soetaert et al., 2004; Struyf et al., 2006). About $44 \%$ of the annual reed production remains as detritus at the end of the season, or 1782 tonnes in total. A large part of this detritus entered
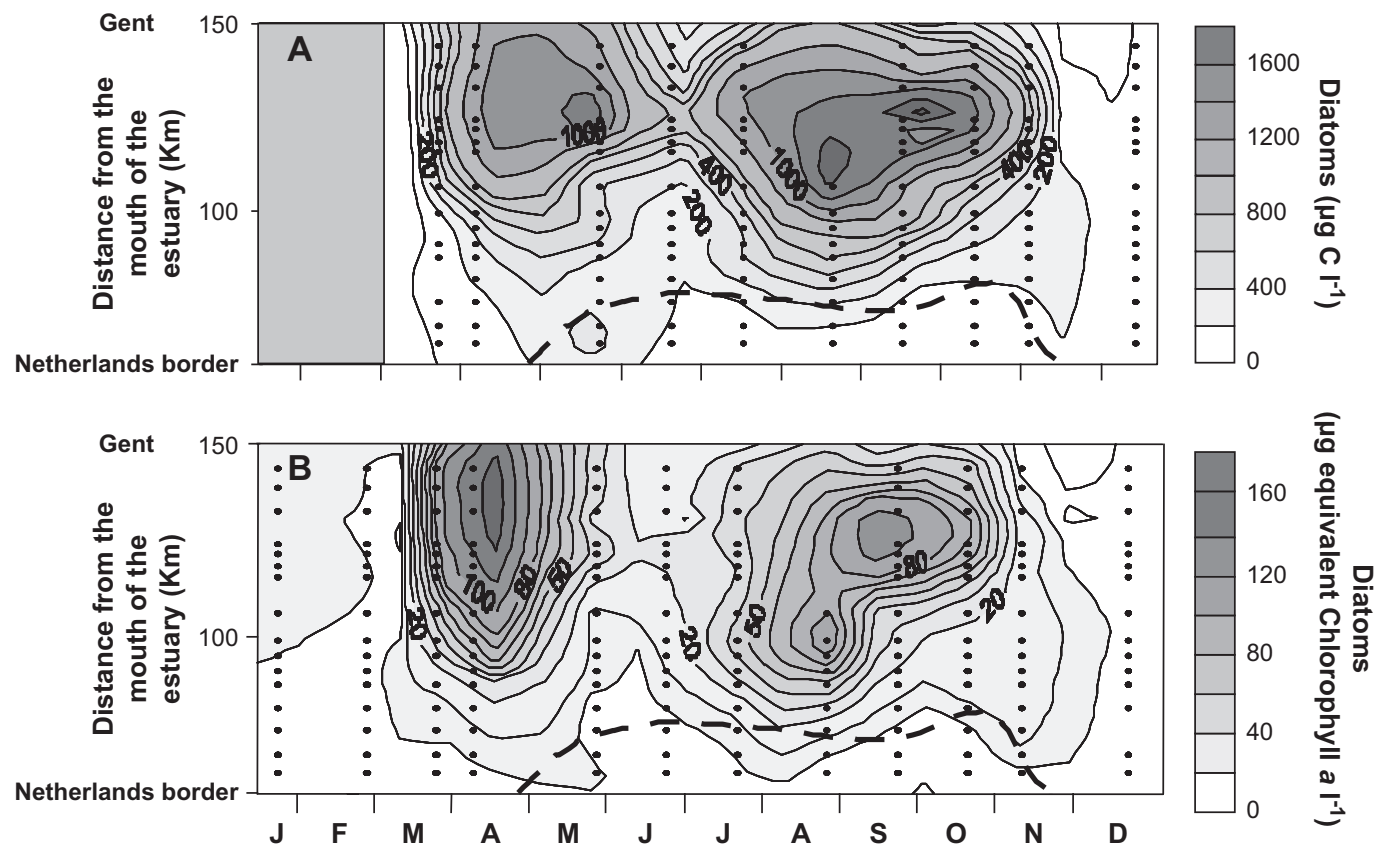

Fig. 5. Spatio-temporal variation of diatoms in the upper Schelde estuary in 2002 estimated by microscope $\left(\mu \mathrm{g} \mathrm{C} 1^{-1}\right.$, A) and HPLC-CHEMTAX analyses $(\mu \mathrm{g}$ equivalent chlorophyll $\left.a 1^{-1}, \mathrm{~B}\right)$. The 5 psu isohaline is represented by the dotted line. Black dots represent sample points in space and time. 

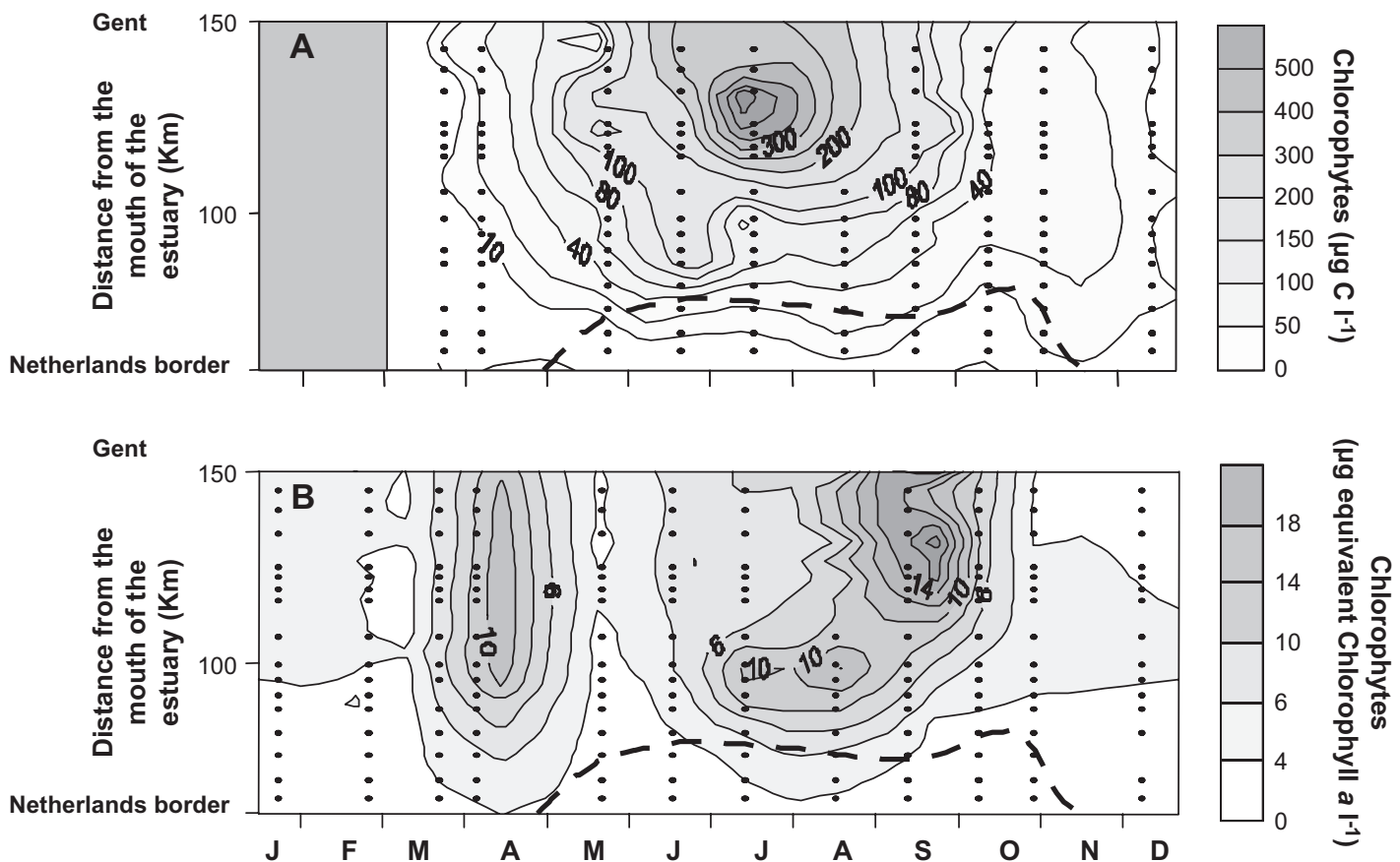

Fig. 6. Spatio-temporal variation of chlorophytes in the upper Schelde estuary in 2002 estimated by microscope $\left(\mu \mathrm{g} \mathrm{C} 1^{-1}\right.$, A) and HPLC-CHEMTAX analyses ( $\mu \mathrm{g}$ equivalent chlorophyll $\left.a 1^{-1}, \mathrm{~B}\right)$. The 5 psu isohaline is represented by the dotted line. Black dots represent sample points in space and time.

the estuarine channel. If all reed detritus would enter the estuarine channel, this would result on average in $0.62 \mathrm{mg} \mathrm{Cl}^{-1}$ reed detritus (given a total annual discharge of $2.9 \times 10^{9} \mathrm{~m}^{3}$ ). Moreover, this reed detritus may accumulate in the turbidity maxima in the upper estuary in the same way as sediment particles are accumulated (e.g. Simenstad et al., 1990). In the upper Schelde estuary, particulate organic matter concentrations are high compared to other European estuaries and the $\delta^{13} \mathrm{C}$ ratio of this particulate organic matter points to an important contribution of vascular plant detritus (Hellings et al., 1999). Although pigments in vascular plant detritus are degraded over time, significant amounts of pigments may remain after a relatively long time. Degradation rates of chlorophyll $a$ and $b$ and lutein in vascular plant detritus are in the order of 0.02 day $^{-1}$ (Bianchi and Findlay, 1990), with lutein having the lowest degradation rate. This would result in less than half of the initial amount of pigments being degraded after 1 month. Litter bag experiments carried out in the upper Schelde estuary in which the degradation of reed leaves was monitored indicated chlorophyll $a$ degradation rates of only 0.01 day $^{-1}$ (Luo et al., 2002). The high turbidity and resulting low light levels in the Schelde estuary might slow down the degradation of pigments (e.g. Welshmeyer and Lorenzen, 1987). During the cell counts, plant fragments were frequently observed. In the HPLC analyses, high concentrations of pheophytin $a$, a degradation product of chlorophyll $a$, also pointed to the presence of important amounts of detritus. The ratio of pheophytin to chlorophyll $a$ was on average 0.34 and frequently exceeded 1 in winter or in the brackish reaches (Jiao and $\mathrm{Ni}, 1997)$.
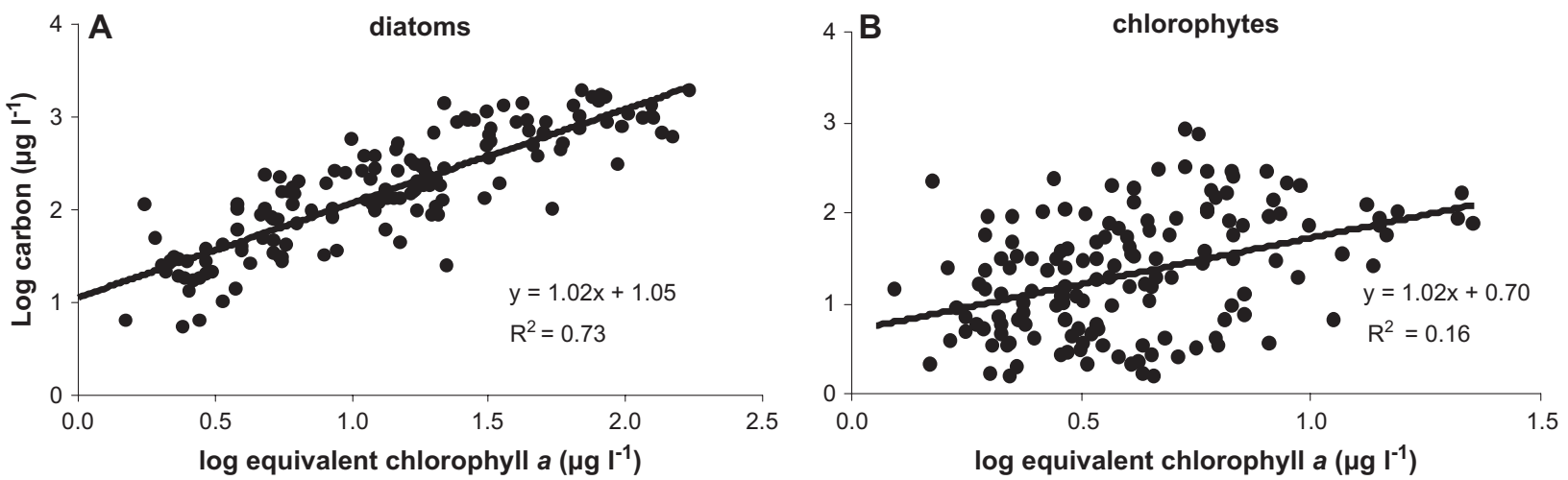

Fig. 7. Regression of A: the diatoms biomass $\left(\log \mu \mathrm{g} \mathrm{Cl}^{-1}\right)$ estimated by microscopic counts versus the diatoms equivalent in chlorophyll $a$ estimated by HPLCCHEMTAX $\left(\log \mu \mathrm{g}\right.$ equivalent chlorophyll $\left.a 1^{-1}\right)$, Pearson's correlation coefficient: $r=0.85, p<0.001, n=148$; and B: the chlorophytes biomass $\left(\log \mu \mathrm{g} C 1^{-1}\right.$ ) estimated by microscopic counts versus the chlorophytes equivalent in chlorophyll $a$ estimated by HPLC-CHEMTAX (log $\mu \mathrm{g}$ equivalent chlorophyll $a 1^{-1}$ ), Pearson's correlation coefficient: $r=0.40, p<0.001, n=148$. 


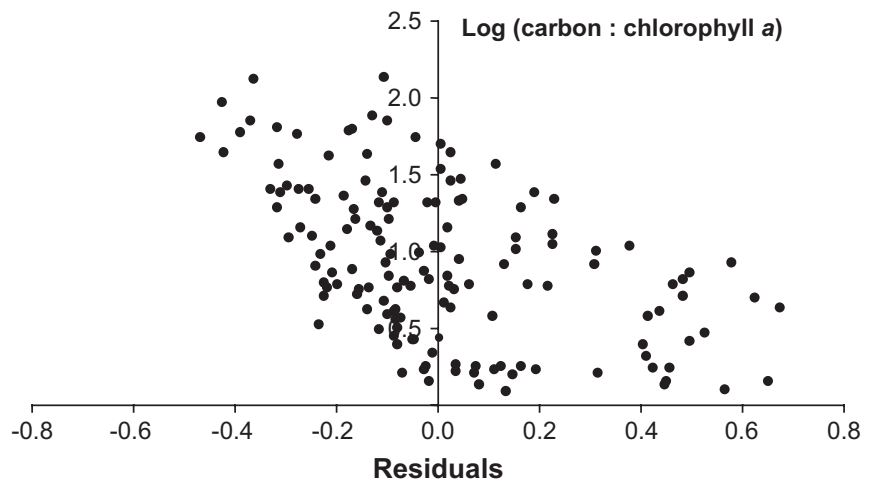

Fig. 8. Regression of carbon to chlorophyll $a$ ratio versus residuals of the regression of chlorophyte biomass versus chlorophytes equivalents in chlorophyll $a$. Pearson's correlation coefficient: $r=-0.51, p<0.001, n=146$.

Pigments present in vascular plant detritus would be detected by HPLC analysis and might result in an overestimation of chlorophyte biomass by CHEMTAX. The contribution of chlorophyll $a$ and $b$ and lutein to the total pigment pool would be negligible in spring and summer in the upper reaches, when phytoplankton biomass is high. But in late autumn and winter, when phytoplankton biomass is low, the contribution of pigments from plant detritus might become important. A concentration of plant detritus of $0.62 \mathrm{mg}^{-1}$ containing $50 \%$ of its pigments would result in a concentration of $5 \mu \mathrm{g}$ chlorophyll $a 1^{-1}$ (assuming an initial carbon to chlorophyll $a$ ratio of 60 in reed leaves; Luo et al., 2002). This is not negligible given the fact that total chlorophyll $a$ was $<21 \mu \mathrm{g} 1^{-1}$ in half of the samples. In the Hudson River estuary, Bianchi et al. (1993) also observed high concentrations of vascular plant pigments near wetlands, indicating important inputs of plant detritus. Near the Prince Edward Islands in the sub-Antarctic, high chlorophyll $a$ levels in water samples were related to the presence of detritus derived from kelp (Kaehler et al., 2006). In North Sea waters near the mouth of the Schelde estuary, where SPM concentrations were elevated, substantial amounts of chlorophyte pigments were observed despite the fact that no chlorophytes were detected during microscopic analyses (Muylaert et al., 2006). Probably, this was also due to the inputs of vascular plant detritus from the estuary.

\section{Conclusion}

In conclusion, our results indicate that HPLC-CHEMTAX was useful for detecting general trends in biomass and community composition of phytoplankton in the turbid upper Schelde estuary. When phytoplankton biomass was low, however, HPLC-CHEMTAX overestimated phytoplankton biomass and general chlorophyte biomass in particular. This was probably due to high concentrations of vascular plant detritus of terrestrial origin. In other ecosystems with high detritus inputs, using pigments as a proxy for phytoplankton biomass and community composition may lead to similar errors when phytoplankton biomass is relatively low, like in wetlands with extensive vegetation beds.

\section{Acknowledgements}

The research presented in this paper was carried out in the framework of the Flemish OMES project ('Onderzoek naar de Milieu-Effecten van het Sigmaplan') coordinated by Professor Patrick Meire. Stefan Van Damme and Tom Maris from the University of Antwerp provided unpublished monitoring data on SPM and salinity.

\section{References}

Ansotegui, A., Sarobe, A., Trigueros, J.M., Urrutxurtu, I., Orive, E., 2003. Size distribution of algal pigments and phytoplankton assemblages in a coastal-estuarine environment: contribution of small eukaryotic algae. Journal of Plankton Research 25, 341-355.

Baeyens, W., Van Eck, G., Lambert, C., Wollast, R., Goeyens, L., 1998. General description of the Scheldt estuary. Hydrobiologia 366, 1-14.

Bianchi, T.S., Findlay, S., 1990. Plant pigments as tracers of emergent and submergent macrophytes from the Hudson River. Canadian Journal of Fisheries and Aquatic Sciences 47, 492-494.

Bianchi, T.S., Findlay, S., Dawson, R., 1993. Organic matter sources in the water column and sediments of the Hudson River estuary. The use of plants pigments as tracers. Estuarine, Coastal and Shelf Science 36, 359-376.

Carreto, J.I., Montoya, N.G., Benavides, H.R., Guerrero, R., Carignan, M.O., 2003. Characterization of spring phytoplankton communities in the Rio de la Plata maritime front using pigment signatures and cell microscopy. Marine Biology 143, 1013-1027.

Geider, R.J., 1987. Light and temperature dependence of the carbon to chlorophyll ratio in microalgae and cyanobacteria: implications for physiology and growth of phytoplankton. New Phytologist 106, 1-34.

Gieskes, W.W.C., Kraay, G.W., 1983. Dominance of cryptophyceae during the phytoplankton spring bloom in the central North Sea detected by HPLC analysis of pigments. Marine Biology 75, 179-185.

Hellings, L., Dehairs, F., Tackx, M., Keppens, E., Baeyens, W., 1999. Origin and fate of organic carbon in the freshwater part of the Scheldt estuary as traced by stable carbon isotope composition. Biogeochemistry 47, 167-186.

Jiao, N., Ni, I.-H., 1997. Spatial variations of size-fractionated chlorophyll, cyanobacteria and heterotrophic bacteria in the central and western Pacific. Hydrobiologia 352, 219-230.

Kaehler, S., Pakhomov, E.A., Kalin, R.M., Davis, S., 2006. Trophic importance of kelp-derived suspended particulate matter in a through-flow sub-Antarctic system. Marine Ecology Progress Series 316, 17-22.

Lewitus, A.J., White, D.L., Tymowski, R.G., Geesey, M.E., Hymel, S.N., Noble, P.A., 2005. Adapting the CHEMTAX method for assessing phytoplankton taxonomic composition in southeastern U.S. estuaries. Estuaries 28, 160-172.

Lionard, M., Azémar, F., Boulêtreau, S., Muylaert, K., Tackx, M., Vyverman, W., 2005. Grazing by meso- and microzooplankton on phytoplankton in the upper reaches of the Schelde estuary (Belgium/The Netherlands). Estuarine, Coastal and Shelf Science 64, 764-774.

Luo, Y., Tackx, M., Li, F.Y., Mao, D.Q., Zhou, Q.X., 2002. Leaf litter ecological fate in the Schelde estuary in Belgium. Journal of Environmental Sciences-China 14, 563-567.

Mackey, M.D., Mackey, D.J., Higgins, H.W., Wright, S.W., 1996. CHEMTAX a program for estimating class abundance for chemical markers: application to HPLC measurements of phytoplankton. Marine Ecology Progress Series 144, 265-283.

Mackey, D.J., Higgins, H.W., Mackey, M.D., Holdsworth, D., 1998. Algal class abundances in the western equatorial Pacific: estimation from HPLC measurements of chloroplast pigments using CHEMTAX. Deep Sea Research, Part I: Oceanographic Research Papers 45, 1441-1468.

Maskymowska, D., Richard, P., Piekarek-Jankowska, H., Riera, P., 2000. Chemical and isotopic composition of the organic matter sources in the Gulf of Gdansk (southern Baltic Sea). Estuarine, Coastal and Shelf Science 51, 585-598. 
Menden-Deuer, S., Lessard, E.J., 2000. Carbon to volume relationships for dinoflagellates, diatoms, and other protist plankton. Limnology and Oceanography $45,569-579$.

Muylaert, K., Sabbe, K., 1999. Spring phytoplankton assemblages in and around the maximum turbidity zone of the estuaries of the Elbe (Germany), the Schelde (Belgium/The Netherlands) and the Gironde (France). Journal of Marine Systems 22, 133-149.

Muylaert, K., Sabbe, K., Vyverman, W., 2000. Spatial and temporal dynamics of phytoplankton communities in a freshwater tidal estuary (Schelde, Belgium). Estuarine, Coastal and Shelf Science 50, 673-687.

Muylaert, K., Van Wichelen, J., Sabbe, K., Vyverman, W., 2001. Effects of freshets on phytoplankton dynamics in a freshwater tidal estuary (Schelde, Belgium). Archiv für Hydrobiologie 150, 269-288.

Muylaert, K., Tackx, M., Vyverman, W., 2005. Phytoplankton growth rates in the freshwater tidal reaches of the Schelde estuary (Belgium) estimated using a simple light-limited primary production model. Hydrobiologia 540, $127-140$

Muylaert, K., Gonzales, R., Franck, M., Lionard, M., Van der Zee, C., Cattrijsse, A., Sabbe, K., Chou, L., Vyverman, W., 2006. Spatial variation in phytoplankton dynamics in the Belgian coastal zone of the North Sea studied by microscopy, HPLC-CHEMTAX and underway fluorescence recordings. Journal of Sea Research 55, 253-265.

Riera, P., Richard, P., 1996. Isotopic determination of food sources of Crassostrea gigas along a trophic gradient in the estuarine bay of MarennesOleron. Estuarine, Coastal and Shelf Science 42, 347-360.

Rodriguez, F., Varela, M., Zapata, M., 2002. Phytoplankton assemblage in the Gerlache and Bransfield Straits (Antarctica Peninsula) determined by light microscopy and CHEMTAX analysis of HPLC pigment data. Deep Sea Research, Part II: Topical Studies in Oceanography 49, 723-747.

Schlüter, L., Møhlenberg, F., Havskum, H., Larsen, S., 2000. The use of phytoplankton pigments for identifying and quantifying phytoplankton groups in coastal areas: testing the influence of light and nutrients on pigment/chlorophyll $a$ ratios. Marine Ecology Progress Series 192, 49-63.
Simenstad, C.A., Small, L.F., McIntire, C.D., Jay, D.A., Sherwood, C., 1990. Columbia river estuary studies: an introduction to the estuary, a brief history, and prior studies. Progress in Oceanography 25, 1-13.

Soetaert, K., Hoffmann, M., Meire, P., Starink, M., Van Oevelen, D., Van Regenmortel, S., Cox, T., 2004. Modeling growth and carbon allocation in two reed beds (Phragmites australis) in the Scheldt estuary. Aquatic Botany 79, 211-234.

Struyf, E., Dausse, A., Van Damme, S., Bal, K., Gribsholt, B., Boschker, E., Middelburg, J., Meire, P., 2006. Tidal marshes and biogenic silica recycling at the land-sea interface. Limnology and Oceanography 51, 838-846.

Thompson, P., 1999. Response of growth and biochemical composition to variations in daylenght, temperature, and irradiance in the marine diatom Thalassiosira pseudonana (Bacillariophyceae). Journal of Phycology 35, 1215-1222.

Van Damme, S., Stuyf, E., Maris, T., Ysebaert, T., Dehairs, F., Tackx, M., Heip, C., Meire, P., 2005. Spatial and temporal patterns of water quality along the estuarine salinity gradient of the Schelde estuary (Belgium and The Netherlands): results of an integrated monitoring approach. Hydrobiologia 540, 29-45.

Welshmeyer, N.A., Lorenzen, C.J., 1987. Chlorophyll budgets: zooplankton grazing and phytoplankton growth in a temperate fjord and the central Pacific Gyre. Limnology and Oceanography 30, 1-21.

Wright, S.W., Jeffrey, S.W., Mantoura, R.F.C., Llewellyn, C.A., Bjørnland, T., Repeta, D., Welschmeyer, N., 1991. Improved HPLC method for the analysis of chlorophylls and carotenoids from marine phytoplankton. Marine Ecology Progress Series 77, 183-196.

Wright, S.W., Jeffrey, S.W., 1997. High resolution system for chlorophylls and carotenoids of marine phytoplankton. In: Jeffrey, S.W., Mantoura, R.F.C., Wright, S.W. (Eds.), Phytoplankton Pigments in Oceanography: A Guide to Advanced Methods. SCOR-UNESCO Publishing, Paris, pp. 327-341.

Wright, S.W., Jeffrey, S.W., Mantoura, R.F.C., 1997. Evaluation of methods and solvents for pigment extraction. In: Jeffrey, S.W., Mantoura, R.F.C., Wright, S.W. (Eds.), Phytoplankton Pigments in Oceanography: A Guide to Advanced Methods. SCOR-UNESCO Publishing, Paris, pp. 261-282. 